\title{
Motivation and Autonomy in Learning English as Foreign Language: A Case Study of Ecuadorian College Students
}

\author{
Jorge Cevallos Bravo ${ }^{1}$, Eder A. Intriago ${ }^{2}$, Jhonny Villafuerte Holguín ${ }^{2,3}$, \\ Gustavo Molina Garzon ${ }^{4} \&$ Luis Ortega $\mathrm{Arcia}^{4}$ \\ ${ }^{1}$ School of Environmental Engineering, Escuela Superior Politecnica Agropecuaria de Manabi, Bolivar, Ecuador \\ ${ }^{2}$ School of Education, Universidad Laica Eloy Alfaro de Manabi, Manta, Ecuador \\ ${ }^{3}$ Fellow of SENESCYT in the doctoral program of Psychodidactics of the University of the Basque Country, \\ Spain \\ ${ }^{4}$ School of Computing, Escuela Superior Politecnica Agropecuaria de Manabi, Bolivar, Ecuador \\ Correspondence: Eder A. Intriago, School of Education, Universidad Laica Eloy Alfaro de Manabí, Manta, ave. \\ universitaria, Ecuador. Tel: 593-5262-3808. E-mail: eder.intriago@uleam.edu.ec
}

Received: December 18, 2016 Accepted: January 14, 2017 Online Published: January 16, 2017

doi: 10.5539/elt.v10n2p100 URL: http://dx.doi.org/10.5539/elt.v10n2p100

\begin{abstract}
This quantitative research aims to examine how different levels of motivation relate to frequency of occurrence of autonomous language learning activities undertaken by undergraduate students. Eight hundred and sixty-two college students from 10 vocational training programs of a public university located in Ecuador, South America, participated in this study. Spratt's questionnaire that regards 'autonomy and motivation' as a cyclical interaction in the language learning process, was updated by the researchers, adding digital education elements. The data were analyzed using the program SPSS v24.0.0 The results showed that there was a significant relationship between: the language learning stimulation generated by professors and the participants' learning attitudes. In addition, it was determined that the most frequent language practices in which the participants showed greatest autonomy were: listening to songs in English language, worrying about the correct pronunciation, and noting down interesting words or expressions in English.
\end{abstract}

Keywords: higher education, foreign language, autonomy and self-correction

\section{Introduction}

The role of motivation in English as a Foreign Language (EFL) has been researched with a strong emphasis on its relationship to language learning achievement (Bernaus \& Gardner, 2009; Dörnyei \& Ushioda, 2013; Patrick Proctor et al., 2014). However, little attention has been paid to the link between motivation and learning autonomy (Spratt et al., 2002; Z. Ma \& R. Ma, 2012; M. C. Cheng \& T. P. Cheng, 2013), even though for most learners, autonomy interlaces their motivation and language learning success.

In that respect, Gardner (1985) argues that motivation implies not only a desire to learn a language, but also a measure of an individual's attitude toward working and striving to achieve a learning objective. Thus, without self-discipline and autonomous effort, motivation itself would not be sufficient to produce desired language learning results in the long term (Pickard, 1995).

For English as a second language (ESL) students, autonomous language learning can implicate engaging in everyday activities such as asking for directions, reading street signs, interacting with friends and talking with acquaintances. In contrast, EFL learners must usually make a greater effort and work more independently to acquire new vocabulary and expressions. Consequently, EFL students see autonomy as a crucial element to learn the target language (Najeeb, 2013).

This research builds on a previous study conducted by Spratt et al. (2002), who regard autonomy and motivation as two elements that interact cyclically in the language learning process. In this paper, learners' autonomy is revealed through a questionnaire by which students report on the outside-class activities they carry out to learn English. The questionnaire incorporates new considerations that are specifically related to recently available learning technologies, which have become more accessible to Ecuadorian students today. 
The researchers explored the relationship between motivation and autonomy in EFL students of a public university in the province of Manabí, Ecuador. The primary aim of the study was to examine how different levels of motivation relate to frequency of occurrence of autonomous language learning activities undertaken by undergraduate students.

Even though research on autonomy is not novel, new studies must emerge to provide insights into the evolution of autonomous language learning strategies and their relationship to the technological resources available to learners.

\section{Literature Review}

\subsection{The Role of Motivation in Language Learning}

Ever since the 1970s, researchers have hypothesized that students with favorable attitudes toward language learning will exhibit high levels of proficiency in the target language (Gardner, 1979; Masgoret \& Gardner, 2003). Motivation is classified as intrinsic and extrinsic (Dickinson, 1995). Intrinsically motivated students enjoy learning a second or foreign language for its own sake, while extrinsically motivated learners, are often persuaded by external rewards associated with language learning (Noels et al., 1999; Falout et al 2009). Vallerand (1997) proposed that language learners with intrinsic motivation tend to produce positive learning results, while extrinsic motivation is more associated with negative learning outcomes. In other words, intrinsically motivated learners retain the content for a longer period, and this retention is self-sustained.

As put forward by Lamb (2002), motivation is crucial for producing positive language learning results even in places with contextual educational constraints. In his study, he found that motivation played an important role in English learning among a group of Indonesian students in disadvantaged educational conditions. Dörnyei and Ushioda (2013) also believe that EFL learning success is related to learners' motivation.

Furthermore, studies show that motivation is enhanced when students produce high language learning achievement (McCombs, 1994; Pintrich \& Schunk, 2002). Spratt et al. (2002) argue that positive learning results foster motivation which in turn intensifies learning success. Motivation plays an important role in L2 achievement. For this reason, it is necessary to view motivation as one of the main factors that trigger learners' ambition to learn an $\mathrm{L} 2$.

\subsection{College Students' Autonomy and Language Learning Process}

Autonomy, from Holec's perspective (1981), is the ability of language learners to manage their own learning using appropriate strategies to obtain a desired language proficiency goal. Some of the strategies selected by autonomous language learners may include: a) finding a suitable learning methodology, b) setting learning goals, c) deciding learning content and pace, d) supervising the learning process, and e) assessing learning achievements objectively (Zhuang, 2010).

Dang (2010) suggests that the concept of autonomy does not only encompass the students' "ability" to take charge of their own education, but it also implicates having the "capacity" to take responsibility for the whole learning process. Driven by this concept, universities and language learning centers have integrated the use of technology into the learning curriculum so as to provide students with the means of promoting and enhancing their autonomy (Yan, 2007).

Learning autonomy can be acquired and fostered through formal education, as indicated by Sanprasert (2010). Language teachers can promote their students`autonomy through appropriate training that encourages students to work independently. For instance, Firth (1997) points out that equipping students with self-monitoring and self-correcting abilities allows them to realize their capacity to teach themselves without much reliance on teacher instruction. Holec (1981) maintains that autonomy is not inborn but must be acquired either by "natural means" or through "formal learning". Because autonomy allows learners to materialize their learning aspirations through hard work and persistent dedication, it plays an essential role in the process of learning an L2.

\subsection{Links between Motivation for Learning and Autonomy}

Dickinson (1995) said that autonomous language learners become more highly motivated when they achieve their expected learning outcomes. In contrast, learners who constantly experience failure in learning a language may end up having a negative attitude towards the target language, which in turn could result in a lack of interest to engage in the process autonomous activities.

Autonomy is viewed by some scholars (i.e. Pintrich, 1999; Vandergrift, 2005) as the result of motivation. They argue that only those who have an interest or motivation (extrinsic or intrinsic) to learn an L2 can have the necessary discipline to engage in hard work and devotion to learning the target language. However, other 
scholars, such as Dörnyei, and Csizér (1998) suggest that motivation comes after autonomy. In fact, a history of debate emerged within the literature as to whether motivation is a cause or an effect of autonomy (Spratt et al., 2002). More recently, in words of Dörnyei and Ushioda (2013) the consensus is that motivation, autonomy and learning achievement are interrelated forming a cyclical process (see Figure 1).

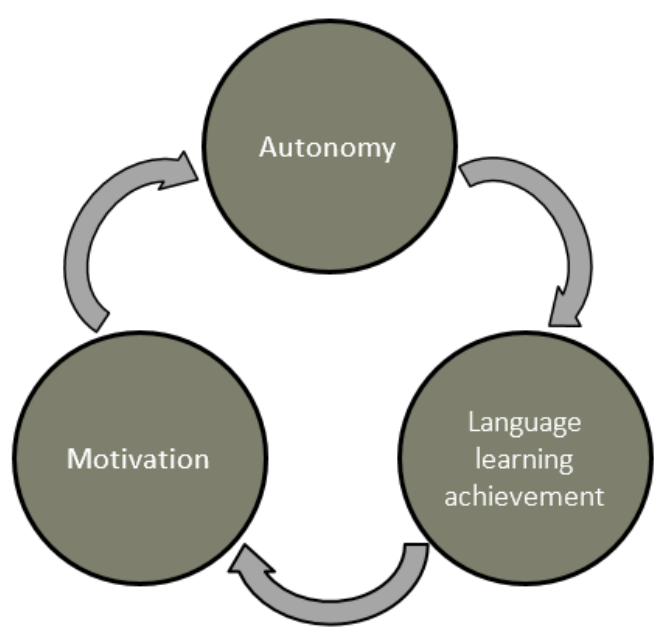

Figure 1. Cyclical process of motivation, autonomy, and achievement in EFL learning

\subsection{Autonomous Language Learning Supported by Technology}

Although the meaning and concept of autonomy have been made clear by researchers over the past decades, autonomous L2 learning strategies have evolved together with the new technological advances. Throughout history, language teachers have incorporated new technologies as tools to facilitate their lesson delivery. The technologies that first had been used in teaching were soon adopted by learners as part of their autonomous language learning activities.

Almost a century ago, Clarke (1918) reported on the importance of speech recording (by means of a phonograph) in teaching pronunciation. Later, in the 1960s and 1970s, the language laboratory became a conspicuous device for L2 instruction (Salaberry, 2001). Television and radio broadcasts (Shmarak \& Dostal, 1965) and video cassette recorders (Swaffar \& Vlatten, 1997) were also integrated in language learning. More recently, the Internet has almost replaced previous L2 learning technologies, especially among young learners (Alias, Manan, Yusof, \& Pandian, 2012). Mobile applications are now accessible to virtually anyone with a smartphone. Researchers agree that today language learners have more access to educational resources than they did before, due to the communication capabilities brought about by the Internet (Blake, 2013). The research questions of this study are as follows:

1) What is the relationship between students' perception of their responsibilities and the ability to learn English as a foreign language?

2) How do different levels of motivation relate to frequency of engagement in outside-class activities carried out by EFL learners?

\section{Methods}

\subsection{Setting and Participants}

The study was conducted in Ecuador in 2015. The participants were students from a language center of a public university in the province of Manabí. The sample consisted of 862 students from seven different academic programs and 10 terms. They were taking English as a compulsory subject as a graduation requirement. The frequency of participation was heterogeneous from $26 \%$ from the first semester and $1.5 \%$ from the tenth semesters. About participants' sex, $50.7 \%$ were female and $49.3 \%$ were male. Almost all participants were teenagers and young adults (average age=20.50; Standard Deviation $\mathrm{SD}=2.73$ ). 
Table 1. Frequency of students by academic program and term

\begin{tabular}{llll}
\hline Academic Program & Frequency & Academic Term & Frequency \\
\hline Agricultural Engineering & 85 & First Semester & 222 \\
Agroindustrial Engineering & 100 & Second Semester & 132 \\
Business Administration & 232 & Third Semester & 153 \\
Computer Engineering & 69 & Fourth Semester & 103 \\
Environmental Engineering & 217 & Fifth Semester & 83 \\
Tourism Management & 77 & Sixth Semester & 38 \\
Veterinary Medicine & 82 & Seventh Semester & 43 \\
& & Eighth Semester & 46 \\
Total & 862 & Ninth Semester & 29 \\
& & Tenth Semester & 13 \\
& & Total & 862
\end{tabular}

Source: ESPAM (2015).

\subsection{Instrument}

The instrument employed in the study was a Likert scale questionnaire, which was adapted from Spratt et al. (2002). The researching team made modifications to the original questionnaire to include language-learning activities that students could do during their classes with the help of available technology (i.e. smartphones, media players, tablets, etc.) that were not massively available when Spratt presented the original instrument. The participants had to choose between 5 alternative answers from ' $1=$ Not at all agree' to ' $5=$ totally agree'. The current version of the questionnaire was analyzed using SPSS v24.0.0 obtaining a Cronbach Alpha index $=.890$ for its 64 items; which represents a high validity and reliability level in accordance with international social research standards.

The questionnaire included a background information section to collect data with regard to participants' academic program, English language level, gender and age; and four main sections (see Appendix 1), which are detailed as follows:

Section 1 contained participants' self-perception of motivation for English learning.

Section 2 explored the participants' perceptions of their professors' stimulation and attitudes to promote engagement in outside and inside class activities to learn English.

Section 3 aimed at identifying participants' autonomous language learning behavior through the actual English learning activities that participants engaged in inside and outside the classroom.

Section 4 explored the determination of the participants' levels of motivation in the execution of autonomous EFL learning activities.

\subsection{Procedures for Data Collection and Analysis}

Before administering the questionnaire, the researchers obtained informed consent from the university authorities. Fifteen English language teachers were instructed, personally and through a video session, about the objective of the study and the content of the questionnaire. This step was not compulsory; however, participants were informed about the importance of their collaboration in order to improve the current service in the Language Center. The researchers asked teachers to request participants to complete the questionnaire thoroughly to obtain a satisfactory response rate. But teachers were also requested to avoid influencing on their students' responses by telling the participants that there were no right or wrong answers. Their answers only had to be consistent with their own beliefs.

Data analysis was carried out by means of SPSS v24.0.0. Comparisons were conducted using items from Section 1 and Section 2 (responsibilities and abilities, respectively), and Section 3 and 4 (motivation and activities, respectively). Chi-square tests were applied to assess the relationship between the differing frequencies of response concerning the following elements: 
a. Relationship about participants' perception of teacher stimulation for EFL autonomous learning vs. their learning attitudes.

b. Relationship about participants' perception of their learning attitudes and their initiatives for EFL practice outside of the class.

c. Univariate analysis between participants' self-perception vs. autonomous EFL learning activities.

\section{Findings}

Section 1: Participants' self-perception of motivation for EFL learning.

To obtain this data, the participants were asked about their self-perception of their level of motivation to learn English. Next are exposed their responses.

Table 2. Participants' self-perception of their motivation for learning English

\begin{tabular}{lllll}
\hline Categories & Frequency & Percentage & $\begin{array}{l}\text { Validated } \\
\text { Percentage }\end{array}$ & $\begin{array}{l}\text { Accumulated } \\
\text { Percentage }\end{array}$ \\
\hline Not at all motivated to learn English & 54 & 6.3 & 6.3 & 6.3 \\
Slightly motivated to learn English & 83 & 9.6 & 9.6 & 15.9 \\
Motivated to learn English & 300 & 34.8 & 34.8 & 50.7 \\
Well-motivated to learn English & 222 & 25.8 & 25.8 & 76.5 \\
Highly motivated to learn English & 203 & 23.5 & 23.5 & 100.0 \\
Total & 862 & 100.0 & 100.0 & \\
\hline
\end{tabular}

Source: Survey (2015).

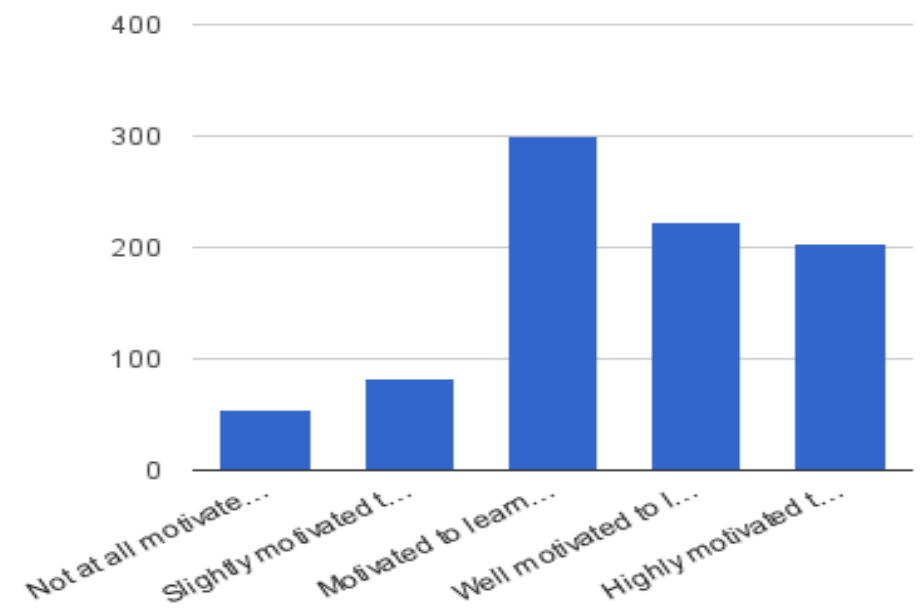

Figure 2. Participants' self-perception of motivation for EFL learning

Section 2: Participants' perception of their teacher's attitudes for the stimulation of engage students in outside and inside English language class activities.

In this statistical analysis, the Chi-square of Pearson is used to determine the relationships between participants' perceptions of their attitudes towards EFL learning and their professors' stimulation for learning. 
Table 3. Relationship between teachers' stimulation and participants attitudes for foreign language learning

\begin{tabular}{|c|c|c|c|}
\hline Items & $\begin{array}{l}\text { Chi square } \\
\text { Pearson }\end{array}$ & $\mathrm{f}$ & $\mathrm{p}$ value \\
\hline $\begin{array}{l}\text { 1. Verify you achieve the learning objectives set out in the English } \\
\text { language course? }\end{array}$ & 16.66 & 2 & 0.000 \\
\hline $\begin{array}{l}\text { 2. Make sure you engage in outside class activities related to } \\
\text { language learning? }\end{array}$ & 13.82 & 2 & 0.001 \\
\hline $\begin{array}{l}\text { 3. Identify the methodology that keeps you motivated to learn } \\
\text { English outside class? }\end{array}$ & 3.88 & 2 & 0.143 \\
\hline 4. Recognize your difficulties and challenges in learning English? & 25.38 & 2 & 0.000 \\
\hline 5. Make you work harder? & 6.58 & 2 & 0.037 \\
\hline 6. Choose the focus and objectives of your English course? & 4.75 & 2 & 0.093 \\
\hline 7. Choose the content of your next English lesson? & 32.09 & 2 & 0.000 \\
\hline $\begin{array}{l}\text { 8. Create the learning environment that keeps you motivated to } \\
\text { learn English? }\end{array}$ & 29.46 & 2 & 0.000 \\
\hline $\begin{array}{l}\text { 9. Make sure you find the opportunity to use English with a } \\
\text { foreigner outside class? }\end{array}$ & 5.88 & 2 & 0.053 \\
\hline $\begin{array}{l}\text { 10. Increase your awareness of your errors in listening, reading, } \\
\text { speaking and writing? }\end{array}$ & 39.28 & 2 & 0.000 \\
\hline $\begin{array}{l}\text { 11. Stimulate your interest in using additional materials (books, } \\
\text { dictionaries, magazines, }\end{array}$ & 8.01 & 2 & 0.018 \\
\hline 12. Assess your progress in learning English? & 36.59 & 2 & 0.000 \\
\hline $\begin{array}{l}\text { 13. Decide how long you spend on your learning activities outside } \\
\text { class? }\end{array}$ & 53.80 & 2 & 0.000 \\
\hline
\end{tabular}

Source: Survey (2015).

The application of Chi - square of Pearson showed a significant relationship between almost all the participants' perceptions of their teachers' stimulations and participants' attitudes for EFL learning under the condition Chi-square Pearson $<=.05$; except for the items: No. 6 (Choose the focus and objectives of your English course?) Chi-square Pearson $=.093$; and item No. 9 (Make sure you find the opportunity to use English with a foreigner outside class?) Chi-square Pearson $=.053$.

Section 3: Identifying participants` autonomous language learning behavior through the actual English learning activities that participants engaged in inside and outside the classroom.

Chi-Square of Pearson was applied to determine the relationship between participants EFL attitudes and their initiatives for the autonomous practice of EFL. 
Table 4. Participants' learning attitudes and autonomy

\begin{tabular}{lllll}
\hline Items: Section 1. Participants attitudes & $\begin{array}{l}\text { Items: Section 2. Participants' } \\
\text { perception of their initiatives for EFL } \\
\text { for EFL learning }\end{array}$ & $\begin{array}{l}\text { Chi-square } \\
\text { Pearson }\end{array}$ & df & P \\
& &
\end{tabular}

1. Verify you achieve the learning objectives set out in the English language course?

2. Make sure you engage in outside class activities related to language learning?

3. Identify the methodology that keeps you motivated to learn English outside class?

4. Recognize your difficulties and challenges in learning English?

7. Choose the content of your next English lesson?

9. Make sure you find the opportunity to use English with a foreigner outside class?

10. Increase your awareness of your errors in listening, reading, speaking and writing?

11. Stimulate your interest in using additional materials (books, dictionaries, magazines,

12. Assess your progress in learning English?

13.Decide how long you spend on your learning activities outside class?
14. Assessing your achievement of the learning 7 set out in the English

44.92 language course?

15. Engaging in outside class activities related to language learning?

$2 \quad 0.000$

16. Choosing a learning approach that keeps you motivated to learn English outside class

21. Identifying your weaknesses in English?

16.96

20.000

17. Giving ideas to your teacher about learning activities to use in your next class?

11.30

$2 \quad 0.004$

24. Finding the opportunity to use English with a foreigner outside class?

8.40

$2 \quad 0.015$

19. Noticing your own errors when using English to communicate with other people?

50.10

$2 \quad 0.000$

22. Using additional materials (books, dictionaries, etc.) and electronic devices (tablets, smartphones, etc.) for learning 20.75 20.000 English outside class?

23. Evaluating your progress in learning English?

50.88

20.000

20. Deciding how long you spend on your English learning activities outside class?

Source: Survey (2015). 
Table 5. Participant' learning attitudes and EFL autonomous practice

\begin{tabular}{|c|c|c|c|}
\hline $\begin{array}{l}\text { Section 1. Participants attitudes for EFL } \\
\text { learning }\end{array}$ & $\begin{array}{l}\text { Section 2. Participants' perception of their } \\
\text { initiatives for EFL practice }\end{array}$ & $\begin{array}{l}\text { Chi } \\
\text { square } \\
\text { Pearson }\end{array}$ & $\begin{array}{l}\mathrm{P} \\
\text { value }\end{array}$ \\
\hline $\begin{array}{l}\text { 1. Verify you achieve the learning } \\
\text { objectives set out in the English language } \\
\text { course? }\end{array}$ & $\begin{array}{l}\text { 14. Assessing your achievement of the } \\
\text { learning objectives set out in the English } \\
\text { language course? }\end{array}$ & 44.92 & 0.000 \\
\hline $\begin{array}{l}\text { 2. Make sure you engage in outside class } \\
\text { activities related to language learning? }\end{array}$ & $\begin{array}{l}\text { 15. Engaging in outside class activities } \\
\text { related to language learning? }\end{array}$ & 18.39 & 0.000 \\
\hline $\begin{array}{l}\text { 3. Identify the methodology that keeps you } \\
\text { motivated to learn English outside class? }\end{array}$ & $\begin{array}{l}\text { 16. Choosing a learning approach that } \\
\text { keeps you motivated to learn English } \\
\text { outside class }\end{array}$ & 16.96 & 0.000 \\
\hline $\begin{array}{l}\text { 4. Recognize your difficulties and } \\
\text { challenges in learning English? }\end{array}$ & $\begin{array}{l}\text { 21. Identifying your weaknesses in } \\
\text { English? }\end{array}$ & 11.30 & 0.004 \\
\hline $\begin{array}{l}\text { 7. Choose the content of your next English } \\
\text { lesson? }\end{array}$ & $\begin{array}{l}\text { 17. Giving ideas to your teacher about } \\
\text { learning activities to use in your next class? }\end{array}$ & 28.28 & 0.000 \\
\hline $\begin{array}{l}\text { 9. Make sure you find the opportunity to } \\
\text { use English with a foreigner outside class? }\end{array}$ & $\begin{array}{l}\text { 24. Finding the opportunity to use English } \\
\text { with a foreigner outside class? }\end{array}$ & 8.40 & 0.015 \\
\hline $\begin{array}{l}\text { 10. Increase your awareness of your errors } \\
\text { in listening, reading, speaking and writing? }\end{array}$ & $\begin{array}{l}\text { 19. Noticing your own errors when using } \\
\text { English to communicate with other people? }\end{array}$ & 50.10 & 0.000 \\
\hline $\begin{array}{l}\text { 11.Stimulate your interest in using } \\
\text { additional materials (books, dictionaries, } \\
\text { magazines, }\end{array}$ & $\begin{array}{l}\text { 22. Using additional materials (books, } \\
\text { dictionaries, etc.) and electronic } \\
\text { devices (tablets, smartphones, etc.) for } \\
\text { learning English outside class? }\end{array}$ & 20.75 & 0.000 \\
\hline $\begin{array}{l}\text { 12. Assess your progress in learning } \\
\text { English? }\end{array}$ & $\begin{array}{l}\text { 23. Evaluating your progress in learning } \\
\text { English? }\end{array}$ & 50.88 & 0.000 \\
\hline $\begin{array}{l}\text { 13.Decide how long you spend on your } \\
\text { learning activities outside class? }\end{array}$ & $\begin{array}{l}\text { 20. Deciding how long you spend on your } \\
\text { English learning activities outside class? }\end{array}$ & 14.95 & 0.001 \\
\hline
\end{tabular}

Source: Survey (2015).

In this case, all the relationships obtained a Chi-square of Pearson $<=.05$; which established the correlation among all the items compared. These results showed a significant relationship between participants' attitudes towards learning English and their being autonomous learners.

Section 4: Determination of the participants' levels of motivation in the execution of autonomy EFL learning activities. In the following table, it is possible to observe the EFL practice that participants can carry out (always) autonomously or (never) or not. 
Table 6. Participants' learning attitudes and EFL autonomous practice

\begin{tabular}{|c|c|c|c|c|c|}
\hline EFL Autonomous practices & Never & Rarely & Sometimes & $\begin{array}{l}\text { Most of the } \\
\text { time }\end{array}$ & Always \\
\hline read academic or nonacademic material in English? & 10.0 & 37.8 & 39.9 & 9.2 & 3.1 \\
\hline visited websites with information in English? & 18.3 & 30.7 & 35.0 & 12.8 & 3.1 \\
\hline sent e-mails in English? & 57.2 & 28.1 & 10.9 & 2.7 & 1.2 \\
\hline $\begin{array}{l}\text { used a Web App to improve your English on your } \\
\text { cell-phone or other electronic devices? }\end{array}$ & 17.4 & 18.6 & 33.6 & 18.4 & 11.9 \\
\hline listened to podcasts in English? & 28.1 & 34.2 & 24.9 & 8.6 & 4.2 \\
\hline talked to a foreigner in English? & 55.1 & 24.9 & 15.2 & 3.1 & 1.6 \\
\hline (Reading) looked up new words in a dictionary? & 7.3 & 19.1 & 36.8 & 24.4 & 12.4 \\
\hline watched TV programs in English? & 7.8 & 17.7 & 40.6 & 22.4 & 11.5 \\
\hline (Listen) watched a movie in English? & 3.7 & 17.6 & 39.4 & 25.3 & 13.9 \\
\hline (Listen skill) listened to songs in English? & 6.6 & 9.9 & 29.5 & 26.2 & 27.8 \\
\hline written a letter to a friend in English? & 52.2 & 25.6 & 11.7 & 5.8 & 4.6 \\
\hline $\begin{array}{l}\text { (speaking skill) worried about finding the correct } \\
\text { pronunciation of an English word? }\end{array}$ & 6.4 & 10.7 & 26.2 & 31.2 & 25.5 \\
\hline (Writing) chatted online with a foreigner in English? & 68.7 & 17.1 & 9.0 & 3.1 & 2.1 \\
\hline (Reading + Writing) enrolled in an online course in English? & 74.0 & 13.3 & 7.5 & 3.9 & 1.2 \\
\hline $\begin{array}{l}\text { (Writing) noted down interesting words or expressions in } \\
\text { English? }\end{array}$ & 5.5 & 17.3 & 35.5 & 23.0 & 18.8 \\
\hline shared your knowledge of English with a friend? & 7.9 & 24.5 & 36.1 & 21.3 & 10.2 \\
\hline $\begin{array}{l}\text { asked your teacher or other students about something you } \\
\text { would like to learn in English? }\end{array}$ & 8.6 & 24.6 & 34.9 & 19.5 & 12.4 \\
\hline helped your friends with an assignment? & 12.9 & 28.9 & 35.0 & 16.5 & 6.7 \\
\hline used a piece of software in English? & 20.2 & 27.8 & 28.0 & 16.1 & 7.9 \\
\hline taken online quizzes to evaluate your English? & 50.2 & 25.9 & 15.2 & 6.1 & 2.6 \\
\hline done grammar exercises? & 23.8 & 27.3 & 28.4 & 13.7 & 6.8 \\
\hline (Writing) written an essay in English? & 64.6 & 19.4 & 11.4 & 3.1 & 1.5 \\
\hline $\begin{array}{l}\text { challenged your classmates to new English vocabulary and } \\
\text { expressions? }\end{array}$ & 34.9 & 37.0 & 18.8 & 6.6 & 2.7 \\
\hline made suggestions to your teacher? & 39.7 & 33.2 & 17.6 & 6.6 & 2.9 \\
\hline spoken English to your teacher? & 9.2 & 27.7 & 32.4 & 19.7 & 11.0 \\
\hline showed your teacher something you have learned? & 13.1 & 26.5 & 29.6 & 18.8 & 12.1 \\
\hline
\end{tabular}

Source: Survey (2015).

The autonomous activities in which the participants engaged with the most frequency were: listening to songs in English, being worried about pronouncing correctly words in English, and noting down interesting words or expressions in English. At the other extreme, the activities that participants did with the least frequency were: enrolling in an online English language course, chatting online with a foreigner in English, and writing an essay in English. 


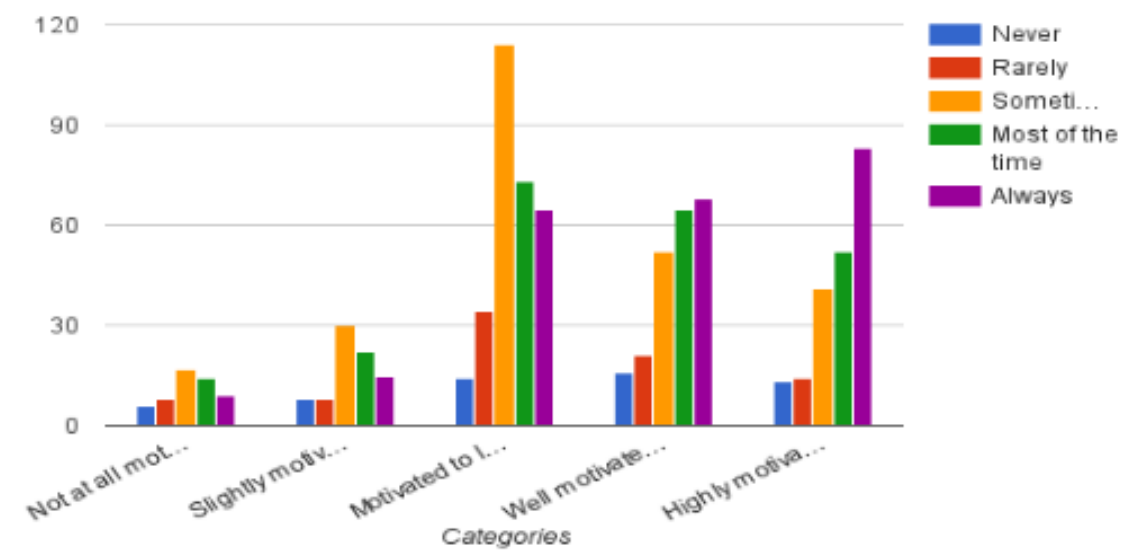

Figure 3. Participants' motivation for listening to songs as and ESL autonomy learning activity

In Figure 3, it is possible to observe in colors orange, green and violet the participants' positive motivation tendency for the item listening to songs as an EFL autonomous practice activity.

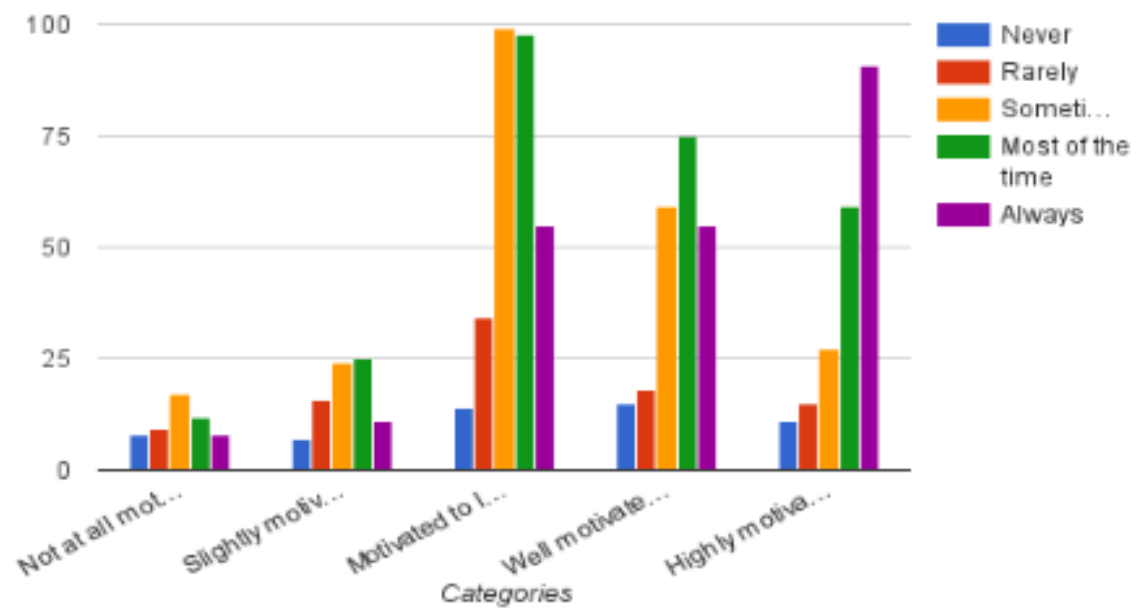

Figure 4. Participants' Autonomous worry about having a correct pronunciation in English language

In Figure 4, the colors orange, green and violet represent the participants' positive motivation tendency about their worry for having a correct pronunciation as EFL autonomous practice. 


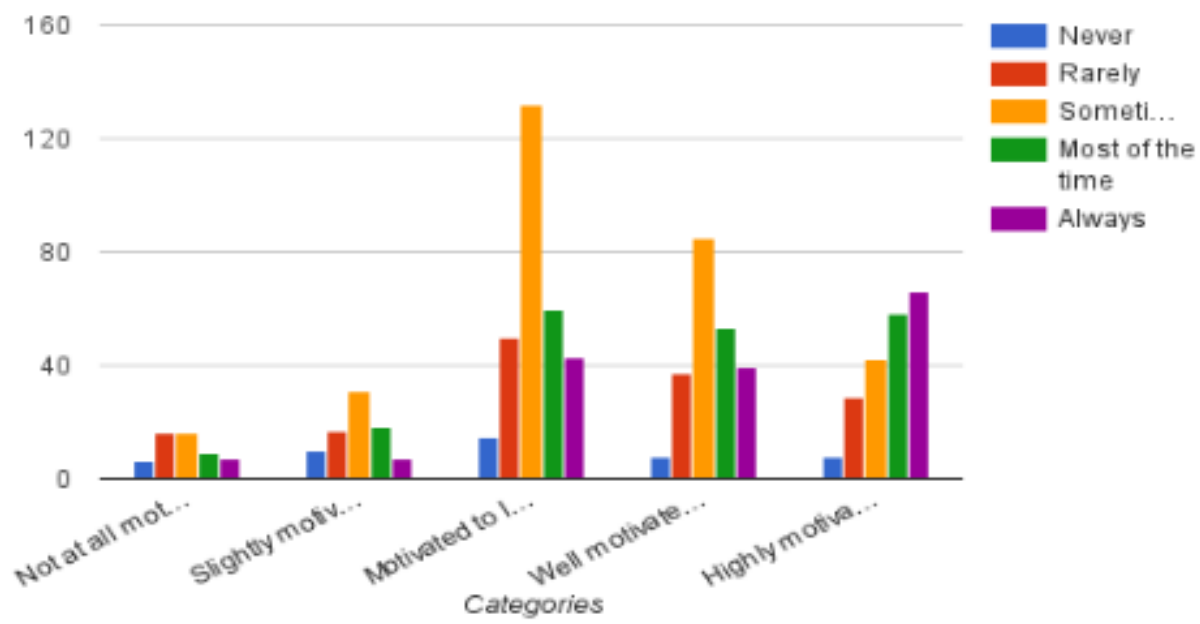

Figure 5. Participants note down interesting words or expressions in English autonomously

In Figure 5, it is observed that the participants are motivated to improve their vocabulary by taking notes autonomously in their process for EFL practice.

\section{Discussion}

In addition to the works developed by Spratt, Humphreys, \& Chan (2002); Ma and Ma (2012); and Cheng and Cheng (2013) about learning motivation and autonomy for learning, this study stems from an Ecuadorian higher education context, where official languages are Spanish, Kichwa and Shuar, but English language learning is highly promoted as a government policy. In such conditions, the process of EFL learning implies cultivating in the students the desire to learn it (Lamb, 2002; Masgoret and Gardner, 2003) which in turn, makes it necessary for learners to become self-disciplined and to engage in autonomous learning (Pickard, 1995). These two conditions are crucial elements in the process of mastering the foreign language being learned (Najeeb, 2013).

The results of this study ratify the existence of the cyclical interaction between 'autonomy and motivation' proposed by Spratt, Humphreys, \& Chan in 2002. As consequence, using the target language manifested as social interaction activities has helped to reduce people's conscious efforts to learn new vocabulary or common expressions. In this sense, to motivate students to learn English, current processes in Ecuadorian colleges have added to the traditional based-on-the-textbook lessons, new learning strategies and activities to be used not only while in the classroom: intensive and extensive reading activities, listening and singing of songs via karaoke, didactic games and contests; watching movies or videos with subtitles on etc., which has been made possible due to the more and more available technology.

This EFL experience carried out in a university context showed that a high motivation for learning is a key element that promotes a positive attitude for the autonomous learning (Holec, 1981; Vandergrift 2005 \& Dang 2010). Zhuang (2010) presents the positive educational attainment obtained as the result of the adequate selection of suitable methodology, the setting of goals, learning content, the rate at which students learn, and assessment as steps required to support the operation of the learning cycle presented by Dörnyei and Ushioda (2013) to intensify learner's success.

We agree with Yang (2007) and Sanprasert (2010) when they refer to 'autonomy in learning process' as the capability and responsibility that learners have in order to self-manage their educational strategies. Also, we value the contribution that technology brings as a powerful tool to enhance foreign language autonomous learning in South American countries, where, in the last two decades, many of the educational reforms being made incorporate the use and promotion of technology to learn, teach and evaluate a second or foreign language. Thus, we consider that educational technology should be applied extensively and intensively to support the improvement of the Ecuadorian educational system in general.

In relation to the category motivation, the results obtained showed that most of the participants chose a position between motivated and highly motivated for EFL learning. These results agree with the attitudes for EFL learning in Spatt's (2002) questionnaire, in which ten of the thirteen attitudinal items showed a clear tendency to 'high motivation for EFL learning'. These findings could also be the result of one of the Ecuadorian policies put into effect: promoting English Language learning as the language that improves the access to advanced 
technology, better work positions, cultural exchange programs, opportunities to pursue undergraduate and graduate degrees in English speaking countries among others. These reasons, it could be argued, have been the triggers of participants' intrinsic or extrinsic motivations in coherence with studies on motivation by Falout, Elwood, \& Hood (2009); and Dörnyei and Ushioda (2013).

As for the relationship between participants' learning attitudes and their autonomy to engage in activities to learn English, the results showed a significant relationship in every item studied which confirms the levels of motivation already determined. However, the researchers wonder about such high levels of autonomy in terms of for how long the student remains motivated and what helps to maintain it, because, it has been observed quite frequently, that many college students find it difficult to execute and complete adequately 'short and long term autonomous projects'. This reality may have its answers in the limitations of the current educational system in Ecuador, where behaviorism and teacher-centeredness still reign in the three levels of educations. So, the attempts to change this model usually finds not only resistance from students, but also from a teacher that is not willing to give up control of her class in exchange for autonomous learning practice. Even so, processes of improvement have been set into motion that seek to promote autonomy in learning from primary to higher education institutions. This, of course, demands of teachers and professor to be trained to help in the process and create the so much longed independent autonomous learner

Finally, in Ecuador, there is still an extrinsic motivation centered on qualification, which moves teachers and students away from the true goal of education for sustainable development required in the 21st century, which seeks to ensure that students receive an education directed towards universal learning in which motivation for learning and autonomous learning already are key elements.

\section{Conclusion}

This work reached the aims proposed. The levels of motivation related to frequency of occurrence of autonomous language learning activities undertaken by undergraduate students were examined. The results confirmed Spratt's (1998) position related to 'autonomy and motivation' factors in the sense that they create a cyclical interaction in the EFL learning process. In this research, other factors that also add to the dynamism of language teaching and learning were introduced: 'technological devices' and "stimulation from the teachers'. Based on the results of the Chi-square of Pearson, there were significant relationships between: the language learning stimulation performed by professors and participants learning attitudes at a high frequency level and the activities that showed greater autonomy were: listening to songs, worrying about correct pronunciation, and noting down interesting words or expressions in English. It is deduced from the above, that learners have an open interest to master the target language by learning and using vocabulary, correctly pronounced. This may be an indication that learners find lexis more important than syntax when it comes to choosing activities to master the new language. Additionally, because listening to songs in English is an out-of-the class activity, and in fact, the most popular learning activity among the participants, the implication may seem to make it part of the lessons delivered inside the classroom.

On the other hand, the activities that Ecuadorian EFL learners did with the least frequency were: enrolling in an online English language course, chatting online with a foreigner in English, and writing an essay in English. Learning is still seen as teacher dependent and as such, the idea of going to a website to learn a language is difficult to grasp as effective. It is well known that a central principle in language acquisition is being exposed to the language. Websites and resources that involve interaction (chat-rooms, wikis, blogs) the Internet should be encouraged and made clear to the learners as complementary for language learning. As for academic writing, mostly reflected as an essay, the culture of developing higher levels of thinking and reflection through this form of composition is almost inexistent. Using it as an opportunity for EFL learners to learn how to write and try out new language (structures, phrases, and words); although desirable for its evident benefits, is even less absent in the EFL classroom.

\section{References}

Alias, A. A., Ab Manan, N. A., Yusof, J., \& Pandian, A. (2012). The Use of Facebook as Language Learning Strategy (LLS) Training Tool on College Students' LLS Use and Academic Writing Performance. Procedia-Social and Behavioral Sciences, 67, 36-48. https://doi.org/10.1016/j.sbspro.2012.11.305

Bernaus, M., Wilson, A., \& Gardner, R. (2009). Teacher's motivation, classroom strategy use, students' motivation and second language achievement. Porta Linguarum, 12, 25-36.

Blake, R. J. (2013). Brave new digital classroom: Technology and foreign language learning. Georgetown University Press. 
Chang, M. M. (2005). Applying self-regulated learning strategies in a web-based instruction: An investigation of motivation perception. Computer Assisted Language Learning, 18(3), 217-230. https://doi.org/10.1080/09588220500178939

Cheng, M. C., \& Cheng, T. P. (2013). Reflections of the Role of Motivation on Learning English for Successful College EFL Learners in Taiwan. World Journal of Education, 2(5), 8-14.

Clarke, C. C. (1918). The phonograph in modern language teaching. The Modern Language Journal, 3(3), 116-122. https://doi.org/10.1111/j.1540-4781.1918.tb03384.x

Dang, T. T. (2010). Learner autonomy in EFL studies in Vietnam: A discussion from a sociocultural perspective. English Language Teaching, 3(2), 3-9. https://doi.org/10.5539/elt.v3n2p3

Dickinson, L., (1995). Autonomy and motivation: a literature review. System, 23(2), 165-174. https://doi.org/10.1016/0346-251X(95)00005-5

Dörnyei, Z. \& Csizér, K. (1998). Ten commandments for motivating language learners: results of an empirical study. Language Teaching Research, 2(3), 203-229. https://doi.org/10.1177/136216889800200303

Dörnyei, Z., \& Ushioda, E. (2013). Teaching and researching: Motivation. Routledge.

Falout, J., Elwood, J., \& Hood, M. (2009). Demotivation: Affective states and learning outcomes. System, 37(3), 403-17. https://doi.org/10.1016/j.system.2009.03.004

Gardner, R. C. (1979). Social-psychological aspects of second language acquisition. In H. Giles, \& R. St. Clair, (Eds.). Language and social psychology (pp. 193-220). Oxford: Blackwell.

Stern, H. H. (1975). What can we learn from the good language learner? Canadian Modern Language Review, 31(2), 304-318.

Holec, H. (1981). Autonomy and Foreign Language Learning. Oxford: Pergamon.

Lamb, M. (2002). Explaining successful language learning in difficult circumstances. Prospect, 17(2), 35-52.

Ma, Z., \& Ma, R. (2012). Motivating Chinese Students by Fostering Learner Autonomy in Language Learning. Theory Pract. Lang. Stud. 2. https://doi.org/10.4304/tpls.2.4.838-842

Masgoret, \& Gardner, (2003). Attitudes Motivation, and Second Language Learning: A Meta-Analysis of Studies Conducted by Gardner and Associates. Language Learning, 167-221. https://doi.org/10.1111/1467-9922.00227

Ministry of Education of Ecuador. (2014). Acuerdo 052-14. Disponible en http://educacion.gob.ec/wp-content/uploads/downloads/2014/03/ACUERDO-052-pdf

Najeeb, S. S. R. (2013). Learner Autonomy in Language Learning. Procedia - Soc. Behav. Sci., Akdeniz $\begin{array}{llllll}\text { Language } \quad \text { Studies } \quad \text { Conference, } & \text { May, 2012, Turkey }\end{array}$ https://doi.org/10.1016/j.sbspro.2013.01.183

Naiman, N., Frohlich, N, Stern, H., \& Todesco, A. (1978). The good language learner Research in Education Series, vol. 7 Ontario Institute for Studies in Education (OISE) Press, Toronto, Ontario.

Noels, K. A., Clement, R., \& Pelletier, L. G. (1999). Perceptions of teachers' communicative style and students' intrinsic and extrinsic motivation. The Modern Language Journal, 83(1), 23-34. https://doi.org/10.1111/0026-7902.00003

Oxford, R. L. (1990). Language learning strategies: What every teacher should know. Boston: Heinle \& Heinle.

Patrick Proctor, C., Daley, S., Louick, R., Leider, C. M., \& Gardner, G. L. (2014). How motivation and engagement predict reading comprehension among native English-speaking and English-learning middle school students with disabilities in a remedial reading curriculum. Learn. Individ. Differ, 36, 76-83. https://doi.org/10.1016/j.lindif.2014.10.014

Pickard, N. (1995). Out-of-class language learning strategies: three case studies. Language Learning Journal, 12, 35-37. http://dx.doi.org/10.1080/09571739585200391

Pintrich, P. R. (1999). The role of motivation in promoting and sustaining self-regulated learning. International Journal of Educational Research, 31, 459-70. https://doi.org/10.1016/S0883-0355(99)00015-4

Pintrich, P. R., \& Schunk, D. H. (2002). Motivation in education: Theory, research and applications (2nd ed.). New Jersey: Prentice Hall.

Salaberry, M. R. (2001). The use of technology for second language learning and teaching: A retrospective. The 
Modern Language Journal, 85(1), 39-56. https://doi.org/10.1111/0026-7902.00096

Sanprasert, N. (2010). The application of a course management system to enhance autonomy in learning English as a foreign language. System, 38(1), 109-123. https://doi.org/10.1016/j.system.2009.12.010

Shmarak, A., \& Dostal, N. (1965). TNT in TV FLES. The Modern Language Journal, 49(4), 207-210. https://doi.org/10.1111/j.1540-4781.1965.tb00856.x

Spratt, M., Humphreys, G., \& Chan, V. (2002). Autonomy and motivation: Which comes First. Language Teaching Research, 6, 245-266. https://doi.org/10.1191/13621688021r106oa

Swaffar, J., \& Vlatten, A. (1997). A sequential model for video viewing in the foreign language curriculum. The Modern Language Journal, 81(2), 175-188. https://doi.org/10.1111/j.1540-4781.1997.tb01173.x

Vandergrift, L. (2005). Relationships among motivation orientations, metacognitive awareness and proficiency in L2 listening. Applied Linguistics, 26(1), 70-89. https://doi.org/10.1093/applin/amh039

Yan, G. (2007). Autonomous English Learning among Postgraduate EFL Learners in China: A Study of Attitudes and Behaviors. The Journal of Asia TEFL, 4(3), 47-70.

Yang, W., \& Dai, W. (2011). Rote memorization of vocabulary and vocabulary development. English Language Teaching, 4(4), 61-64. https://doi.org/10.5539/elt.v4n4p61

Zhuang, J. (2010). The changing role of teachers in the development of learner autonomy- Based on a survey of "English dorm activity". Journal of Language Teaching and Research, 1(5), 591-595. https://doi.org/10.4304/jltr.1.5.591-595

Zhuang, J. (2010). The Changing Role of Teachers in the Development of Learner Autonomy- Based on a Survey of "English Dorm Activity". Journal of Language Teaching and Research, North America, 1, sep. 2010. https://doi.org/10.4304/j1tr.1.5.591-595

\section{Copyrights}

Copyright for this article is retained by the author(s), with first publication rights granted to the journal.

This is an open-access article distributed under the terms and conditions of the Creative Commons Attribution license (http://creativecommons.org/licenses/by/4.0/). 